\title{
Influence of phosphorus and irradiance on phytoplanktonic chlorophyll-a concentration and phosphorus contents at a diel scale in a Mediterranean reservoir
}

\author{
Claudia Feijoó ${ }^{1,2, *}$, Marta Comerma ${ }^{1}$, Rafael Marcé ${ }^{1}$, Juan Carlos García ${ }^{3}$, David Balayla ${ }^{1}$, \\ Enrique Navarro ${ }^{1} \&$ Joan Armengol ${ }^{1}$
}

${ }^{1}$ Fluvial Dynamics and Hydraulic Engineering (FLUMEN), Departament d'Ecologia, Universitat de Barcelona, Diagonal, 645, 08028 Barcelona, Spain.

${ }^{2}$ Programa de Investigaciones en Ecología Acuática, Departamento de Ciencias Básicas, Universidad Nacional de Luján, C.C. 221, (6700) Luján, Argentina.

${ }^{3}$ Aigües Ter-Llobregat, Barcelona, Spain.

*Corresponding author: clasife@ coopenetlujan.com.ar

Received: 2/6/08

Accepted: 5/8/08

\begin{abstract}
Influence of phosphorus and irradiance on phytoplanktonic chlorophyll-a concentration and phosphorus contents at a diel scale in a Mediterranean reservoir

Phosphorus concentration in the water is one of the main factors regulating phytoplankton biomass and productivity in inland water bodies. However, phosphorus uptake by algae could not cause immediate growth, because other factors (light and other nutrient availability) may limit production. Nonetheless, "luxurious" phosphorus uptake (i.e. phosphorus uptake beyond the algal requirements) has been observed, and it has been interpreted as storage to use in situations of low nutrient availability. Thus, the assessment of the effect of phosphorus supply on algal growth is not straightforward, especially at very short time scales.

In this study, we analyze the relationships between environmental phosphorus levels and internal phosphorus and chlorophyll- $a$ contents in phytoplankton at a diel scale in a Mediterranean reservoir, considering the different algal (intracellular and membrane-associated) and water phosphorus pools. We also evaluated the influence of light on these relationships by sampling at two water depths with different irradiance levels. Our hypothesis is that chlorophyll-a and intracellular phosphorus contents in phytoplankton are both influenced by ambient phosphorus and irradiance levels, which are complementary resources for algae as the nutrient-light hypothesis proposes.

Phosphorus concentration and relative contribution of each phosphorus fraction was similar at both sampling depths. Total phosphorus concentration was dominated by the particulate pool (70\%), and dissolved inorganic phosphate represented only one third of the dissolved pool. Total phosphorus content and the relative contribution of the different pools in algal cells were similar at both sampling depths. Intracellular phosphorus pool was on average $77 \%$ of the total nutrient content, while phosphorus associated to membranes represented the remaining of the total pool. Mean intracellular SRP concentration was $36 \%$ of the intracellular phosphorus content. None of the algal phosphorus pools showed significant correlations with underwater light levels at both sampling depths. Total chlorophyll-a concentration showed no significant correlations with the several water phosphorus pools at both sampling depths, because each algal group responded differently to environmental phosphorus levels, and these responses also varied with depth. We found significant relationships between the intracellular phosphorus content and the different phosphorus pools in water, but this almost 'automatic' response of algae to phosphorus levels in water was not reflected in changes in the chlorophyll-a content, at least within the 3-day time frame of this study. A possible explanation is that processes associated to nutrient uptake and biomass construction operate over different time scales. The results of this work emphasize the complexity of the links between environmental phosphorus concentration and phytoplanktonic phosphorus content and biomass, and the importance of scale in analysing such relationships.
\end{abstract}

Key words: Internal algal phosphorus, phytoplankton biomass, phosphorus, wind regime, reservoir, diel cycle. 


\section{RESUMEN}

Influencia del fósforo y de la irradiancia en la concentración de clorofila y contenido de fósforo fitoplanctónico a escala diaria en un embalse mediterráneo

La concentración de fósforo en el agua es uno de los factores principales que regulan la biomasa y producción del fitoplancton. Sin embargo, la asimilación de fósforo por las algas puede no causar un crecimiento inmediato, ya que otros factores (luz u otros nutrientes) pueden limitar la producción. Además, se ha observado la asimilación "lujuriosa” de fósforo (es decir, asimilación que va más allá de los requerimientos algales), lo que se ha interpretado como reserva a ser utilizada en momentos de deficiencia de este nutriente. Por lo tanto, la caracterización del efecto del fósforo en el crecimiento algal no es inmediata, especialmente en escalas de tiempo muy cortas.

En este estudio analizamos las relaciones entre el fósforo ambiental, el fósforo interno y la concentración de clorofila-a fitoplanctónica a escala diaria en un embalse mediterráneo, considerando las diferentes fracciones de fósforo algal (intracelular y asociado a membranas) y en el agua. También evaluamos la influencia de la luz en estas relaciones muestreando a dos profundidades con diferente nivel de irradiación. Nuestra hipótesis es que la clorofila-a y el fósforo intracelular están influenciados por el fósforo ambiental y los niveles de irradiación, tal y como propone la hipótesis nutriente-luz.

La concentración de fósforo y la contribución relativa de cada fracción fueron similares en ambas profundidades. La concentración de fósforo total estuvo dominada por la fracción particulada (70\%), y el SRP representó sólo un tercio de la fracción disuelta. En contenido de fósforo total y la contribución relativa de las diferentes fracciones en las algas fue similar en ambas profundidades. El fósforo intracelular representó el $77 \%$ del contenido total de nutriente, mientras que el fósforo asociado a membranas representó el resto. La concentración promedio de SRP intracelular fue el $36 \%$ del contenido intracelular de fósforo. Ninguno de las fracciones de fósforo en las algas mostró correlación significativa con los niveles de irradiancia en ninguna de las dos profundidades. La concentración de clorofila-a no mostró ninguna correlación con las fracciones de fósforo en ninguna de las dos profundidades, ya que cada grupo algal respondió de forma diferente a los niveles ambientales de fósforo, y estas respuestas también variaron con la profundidad. Encontramos correlaciones significativas entre el contenido de fósforo intracelular y las diferentes fracciones de fósforo en el agua, pero esta respuesta casi "automática" de las algas a los niveles de fósforo no se reflejó en cambios en el contenido de clorofila-a, al menos en el marco de los tres días que duró el estudio. Una posible explicación es que los procesos asociados a la asimilación de nutrientes y aquellos asociados a la síntesis de biomasa operan en escalas de tiempo diferentes. Los resultados de este estudio destacan la complejidad de las relaciones entre la concentración de fósforo ambiental, el contenido de fósforo de las algas y la producción de biomasa, y la importancia de la escala en el análisis de estas relaciones.

Palabras clave: Fósforo algal interno, biomasa fitoplanctónica, fósforo, régimen de viento, embalse, ciclo diario.

\section{INTRODUCTION}

Phosphorus concentration in the water is one of the main factors regulating phytoplankton biomass and productivity in inland water bodies. It is well known that activity, structure, and biomass of the phytoplankton community in the epilimnion may change in response to changes in the nutrient regime (Komárková \& Hejzlar, 1996). Even though dissolved inorganic phosphate is the most readily available form of this element for algal growth, its concentration in epilimnetic water is often insufficient to satisfy phytoplanktonic demand (Wetzel, 2001). Nevertheless, the phosphorus pool is rapidly regenerated by several mecha- nisms (Dodds, 1983; Nalewajco \& Lean, 1980), which included enzymatic hydrolysis of dissolved organic compounds by phosphatases released by microorganisms (Boavida \& Heath, 1984). Therefore it is important to consider all phosphorus fractions when we wish to quantify the whole environmental phosphorus availability.

Phytoplankton growth rate is not only related to the availability of phosphorus and other nutrients, but also to its own physiological phenomena (uptake and assimilation processes considered separately). Thus, growth rate can be related to the average internal nutrient content that is limiting growth (Droop, 1983). Nevertheless, after covering their nutrient requirements, algae 
can continue absorbing nutrients in a process known as 'luxury uptake', and the excess stored can be used in periods of low nutrient availability in water. Algal phosphorus uptake may also be influenced by irradiance level. The lightnutrient hypothesis (Sterner et al. 1997) proposes that high light or low phosphorus supply can lead to phytoplankton biomass that will be carbon rich and phosphorus poor, increasing the $\mathrm{C}: \mathrm{P}$ algal ratio. Within the framework of this hypothesis, Dickman et al. (2006) experimentally analyzed the response of phytoplankton stoichiometry to light and nutrients in reservoirs of varying productivity. They found that the light-nutrient hypothesis was supported and that the effects of light and nutrients on phytoplankton stoichiometry were strongly interactive. They proposed that light and nutrients might serve as complementary resources (Tilman 1982); under limitation by one resource, phytoplankton may use the other, more available resource to partially compensate for the lack of the limiting factor. Consequently, phytoplankton may take up excess nutrients to partially compensate low light levels, resulting in low $\mathrm{C}$ :nutrient ratios. Higher uptake of nutrients may allow phytoplankton to build cellular machinery needed for increasing light absorption (Klausmeier et al. 2004, Dickman et al. 2006).

The phosphorus content of algal cells has been partitioned into intracellular and membrane-associated phosphorus pools, which can contribute differently to the total cellular phosphorus content. The relative contribution of each pool varies under different algal growth. SañudoWilhelmy et al. (2004) observed that surfaceadsorbed phosphorus was higher in senescent than in exponential growing cultures, and suggested that phosphorus uptake by phytoplankton could be a two-step kinetic process: first, phosphorus adsorption to cell surface caused by an inorganic scavenging process, followed by incorporation into the intracellular pool, which would reflect the algal nutritional status more accurately than the phosphorus associated to membranes. This study highlights the importance of considering all phosphorus fractions of phytoplankton to quantify its response to changes in environmental phosphorus levels.
The processes of nutrient uptake and storage by phytoplankton can operate at small time scales. Turnover time of inorganic phosphorus varies from minutes or seconds to hours or days, depending on the trophic state of the water, the predominant phosphorus pool (particulate or soluble), and time of year; the velocity of the process is facilitated by the fact that no redox changes are necessary for algal uptake and metabolism (Harris 1986, Nalewajko \& Lean 1980). In a broader context, significant and often repeatable variations in phytoplankton biology are often induced, and commonly observed, on time scales shorter than a day (Prézelin, 1992); therefore, they are not well documented in phytoplankton studies at the seasonal scale. However, few studies have investigated phytoplankton spatial and temporal dynamics at a diel scale, and they generally lasted only one day (Patterson \& Wilson, 1995; Barbosa et al., 1989; Aleya, 1991).

In this study, we analyze the relationships between environmental phosphorus levels and internal phosphorus and chlorophyll- $a$ contents in phytoplankton at a diel scale in a Mediterranean reservoir, considering the different algal and water phosphorus pools. We also evaluated the influence of light on these relationships by sampling at two water depths with different irradiance levels. Our hypothesis is that chlorophyll- $a$ and intracellular phosphorus contents in phytoplankton are both influenced by ambient phosphorus and irradiance levels, which are complementary resources for algae as the nutrient-light hypothesis proposes. Consequently, our predictions are that:

a) At higher water depth and consequently, lower amounts of light available, phytoplankton phosphorus content will be higher than at lower depth.

b) Water phosphorus content will show a positive relationship with intracellular phosphorus but not with membrane-associated phosphorus of phytoplankton.

c) Chlorophyll-a concentration will be positively related to water phosphorus content, and this relationship will be stronger at lower depth. 
To test our hypothesis, daily changes in water and algae $\mathrm{P}$ contents and chlorophyll- $a$ concentrations were intensively monitored at two different water depths during three diel cycles in Sau Reservoir (Spain).

\section{MATERIALS AND METHODS}

Sau Reservoir (NE Spain) is a eutrophic and monomictic canyon-shaped reservoir that supplies drinking water to Barcelona. The Ter River, the main inflow to Sau Reservoir, is heavily polluted, exhibiting high concentrations of soluble reactive phosphorus and ammonia (Vidal \& Om, 1993; Armengol et al., 1994). The annual pattern of thermal stratification in summer (from April to September) and vertical mixing in winter has been observed in Sau since 1963 (Vidal and Om, 1993; Comerma, 2003). During summer, when the thermal stability of the reservoir water column is high, the river is colder and denser than reservoir's surface waters and river water progressively sinks towards thermocline depth with little mixing with the surrounding reservoir water (Armengol et al., 1999).

The study was conducted in summer between 11th and 14th September 2001. Samples were taken every two hours from a station located about $1000 \mathrm{~m}$ from the dam.

Temperature, $\mathrm{pH}$, conductivity, dissolved oxygen concentration, and turbidity profiles were drawn using a multiparametric probe Turo Water Analyzer. Photosynthetically active radiation (PAR) was measured at different depths with a LI-COR Underwater Radiation Sensor. Chlorophyll- $a$ concentration profiles were estimated with a submersible fluorescent FluoroProbe that can discriminate among the main phytoplanktonic groups (Chlorophyceae, Cyanobacteria, Cryptophyceae, and Bacillariophyceae). Previous to the study, we calibrated the device with algae of different groups cultured from autochthonous populations; in addition, the method's accuracy has also been tested in other studies, which showed that fluorescence measurements were in good agreement with HPLC and microscopic count data (Beutler et al., 2002; Leboulanger et al., 2002).
For the estimation of the different water and algal phosphorus pools, water samples were taken at 2 m-depth and at 6 m-depth with a 5-L capacity Schindler-Patalas hydrographic bottle. Samples were filtered in the field through a $53 \mu \mathrm{m}$ net to eliminate zooplankton, and transported in plastic bottles in the dark to a nearby laboratory, where they were immediately analyzed.

Unfiltered water was used to determine total phosphorus in reservoir water. Samples were previously digested (Grasshoff et al., 1983), and analyzed for reactive phosphorus concentration by the ascorbic acid method (APHA, 1992). Filtered water (Whatmann GF/F glass fiber filters pre-combusted at $450^{\circ} \mathrm{C}$ ) was analysed for dissolved inorganic phosphate (this phosphorus fraction was considered as soluble reactive phosphorus (SRP)) and total dissolved phosphorus (Grasshoff et al., 1983; APHA, 1992). Particulate phosphorus (PP) in water was estimated as the difference between total phosphorus and total dissolved phosphorus, while dissolved organic phosphorus (DOP) was the difference between total dissolved phosphorus and SRP. Considering that the study was focused on surface layers during the stratification period we did not measure sedimentary phosphorus fractions.

Different internal algal phosphorus forms were estimated by filtering water samples through pre-combusted GF/F filters, and boiling filters in water at $99^{\circ} \mathrm{C}$ during one hour to assure the breaking of cells and the release of the intracellular nutrient pool (Thorensen et al., 1982). The resulting extract was then passed through a precombusted GF/F filter. This filter was digested (Grasshoff et al., 1983), and particulate phosphorus (i.e. the phosphorus linked to cell membranes or MP) was estimated by the ascorbic acid method. The concentrations of soluble phosphorus fractions of the filtrate were then estimated by the methods indicated above. From the filtrate we measured the total dissolved phosphorus (assumed to be the total intracellular phosphorus, IP) and the internal dissolved inorganic phosphate (measured as reactive phosphorus (SRPi)).

From the raw data obtained with the FluoroProbe (vertical concentration profiles expressed in $\mu \mathrm{g}$ chl- $\left.a \mathrm{~L}^{-1}\right)$, we calculated total chlorophyll- $a$ 


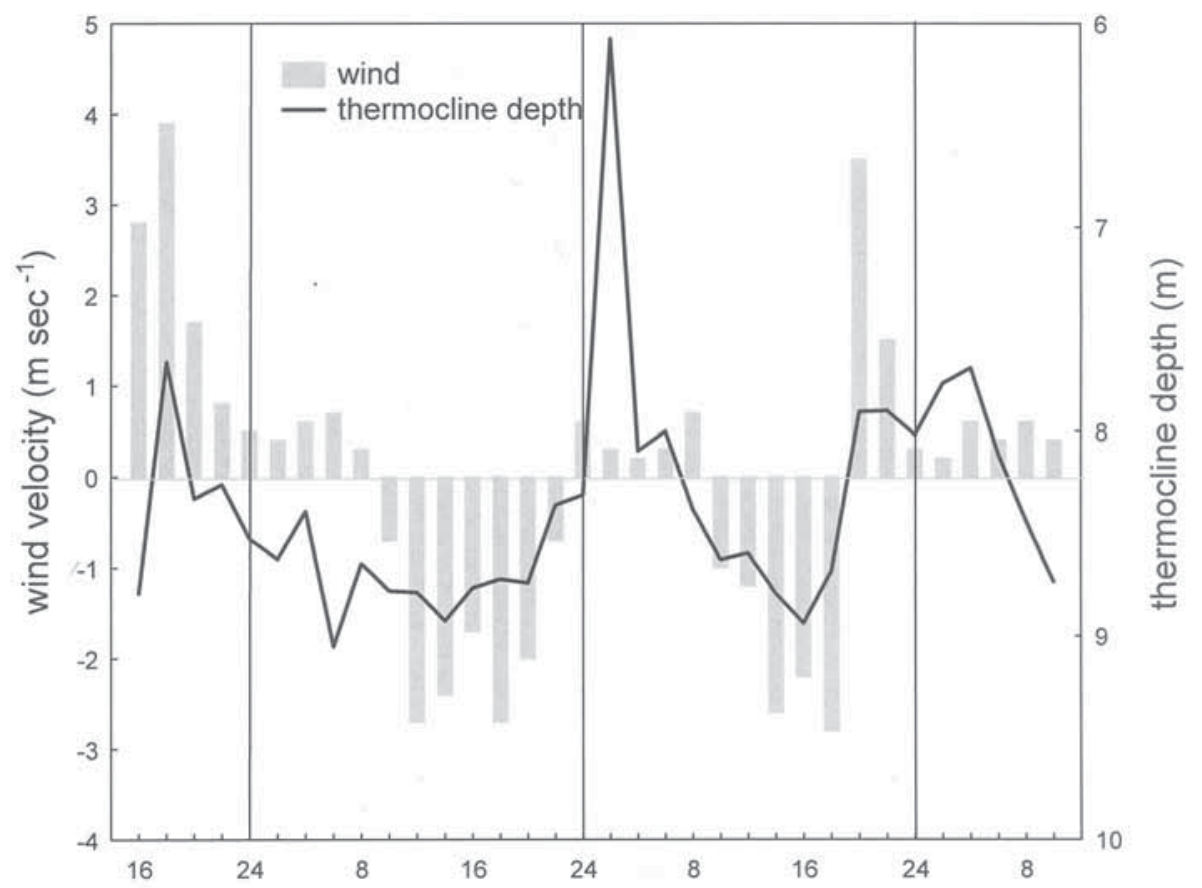

Figure 1. Direction and velocity of the wind and thermocline depth during the sampling days in Sau Reservoir. Positive values of wind velocity indicate that wind blew from the dam wall to the river, while negative values indicate the opposite direction. Dirección y velocidad del viento y profundidad de la termoclina durante los días de muestreo en el embalse de Sau. Valores positivos de la velocidad del viento indican que el viento sopló desde la presa al río, mientras que valores negativos indican la dirección opuesta.

concentration in a water column of $7 \mathrm{~m}$-depth (from the water surface to the bottom of the epilimnion), obtaining the chlorophyll- $a$ content per unit surface ( $\mathrm{mg}$ chl- $a \mathrm{~m}^{-2}$ ) at each sampling occasion.

To determine thermocline depth, we established the depth at which the maximum temperature difference was observed for each temperature profile recorded in all sampling occasions $(N=34)$. Then, we estimated water temperature at this depth by linear interpolation down each profile, and averaged all the estimated temperatures to obtain a value of $19.51^{\circ} \mathrm{C}$. The depth of the $19.51^{\circ} \mathrm{C}$ isotherm was determined by linear interpolation for each sampling point, and this was used as a representation of thermocline depth.

Wedderburn number (W) (Imberger \& Patterson, 1990) was also calculated for each sampling occasion. This is an index of mixing potential and the degree of tilting of a thermocline in lentic environments, which combines the effects of stability, wind forcing, and mixed-layer aspect ratio into a single parameter.
Meteorological data were recorded by a Campbell Scientific Station situated $200 \mathrm{~m}$ from the shoreline and $12 \mathrm{~m}$ above the water surface when the reservoir is at maximum capacity.

Nonparametric Spearman rank correlations were applied to explore the relationships between variables.

\section{RESULTS}

\section{Weather conditions and physico-chemical characterization of the system}

Weather was stable during the study period. Air temperature increased along the sampling days with higher values between 16:00 and 18:00 h, while atmospheric pressure decreased. Maximum solar radiation was recorded at 14:00 $\mathrm{h}$. Wind regime showed a diel regular pattern (Fig. 1): during day, wind blew from the river towards the dam (W-SW) while it blew in the opposite direction during the night (E-NE), as a light sea breeze. 

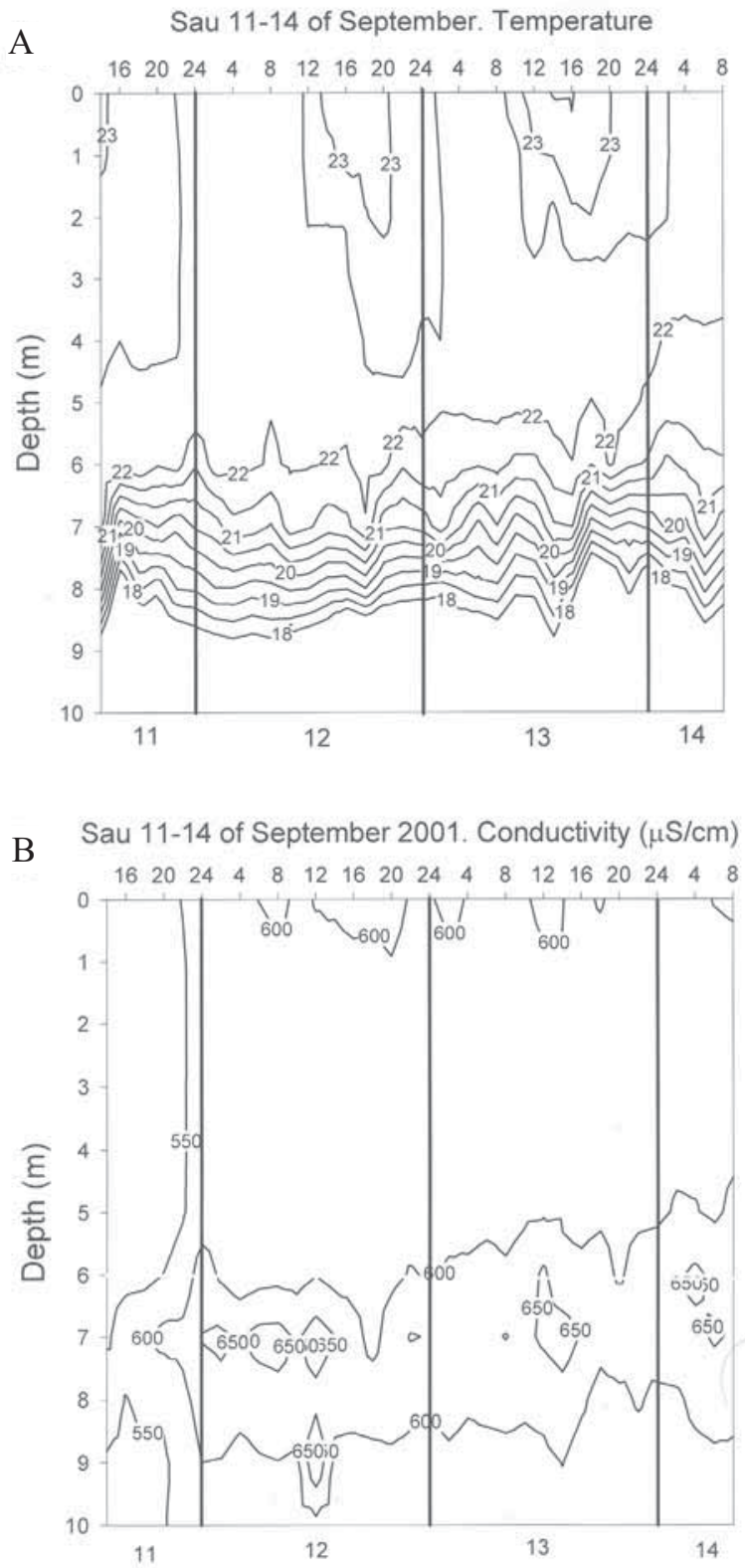

Figure 2. Vertical profiles of (A) temperature $\left({ }^{\circ} \mathrm{C}\right)$, and (B) conductivity $\left(\mu \mathrm{S} \mathrm{cm}^{-1}\right)$ in Sau Reservoir during the sampling days. Perfiles verticals de $(A)$ temperature $\left({ }^{\circ} C\right)$ y $(B)$ conductividad $\left(\mu \mathrm{S} \mathrm{cm}^{-1}\right)$ en el embalse de Sau durante los días de mиеstreo.

Wedderburn number (W) estimated for each sampling occasion was always higher than 10 with a mean value of 591, indicating the lack of mixing, high thermal stability, and a clear stratification profile in Sau Reservoir during the study. Thermocline was situated between 6 and
9 m-depth and oscillated in relation to wind ( $r=-0.49, P<0.01$ ) (Fig. 1 and 2A). Therefore, when the wind blew towards the river (positive wind values), thermocline moved upwards, while it deepened when the wind blew in the opposite direction. Highest water temperatures were $23-24^{\circ} \mathrm{C}$ and were recorded during the afternoon (13:00-20:00 h) (Fig. 2A). Oxygen saturation was $20-130 \%$, and its profile was similar to that of water temperature. Unlike temperature and oxygen saturation, conductivity did not show a daily pattern. Largest conductivities, which evidence the presence of Ter $\mathrm{Ri}$ ver waters (Armengol et al. 1999), were observed at $7 \mathrm{~m}$ depth in 29 of the 34 sampling occasions (Fig. 2B), implying an interflow river circulation at the bottom of the epilimnion that was not affected by thermocline oscillation.

As expected, underwater light levels varied along the day at both sampling depths, and they were one order of magnitude higher at $2 \mathrm{~m}$ depth than at $6 \mathrm{~m}$-depth, with mean values of $83.80 \mu \mathrm{mol}$ of photons $\mathrm{m}^{-2} \mathrm{seg}^{-1}$ and $2.52 \mu \mathrm{mol}$ of photons $\mathrm{m}^{-2} \mathrm{seg}^{-1}$, respectively.

\section{Phosphorus in water and in algal cells}

Mean water phosphate concentration was higher at $6 \mathrm{~m}$ than at $2 \mathrm{~m}$-depth, because of the presence of two phosphate concentration peaks at the higher depth (Fig. 3). But when these peaks were excluded from the analysis, concentration and relative contribution of each phosphorus fraction was similar at both sampling depths (Table 1). Total phosphorus concentration was dominated by the particulate pool ( $\cong 70 \%)$, and SRP represented only one third of the dissolved pool. SRP concentration at $2 \mathrm{~m}$-depth increased during the morning and showed lower values during the afternoon and night, but this pattern was not noticeable at 6 m-depth (Fig. 3).

SRP concentration at $6 \mathrm{~m}$-depth showed no significant correlation with thermocline depth, but was related to temperature, conductivity and dissolved oxygen concentrations ( $r$-values were, respectively, $-0.37,0.43$, and -0.40 , with $P<0.05)$. These relationships were not significant at $2 \mathrm{~m}$-depth. Consequently, high phosphate 

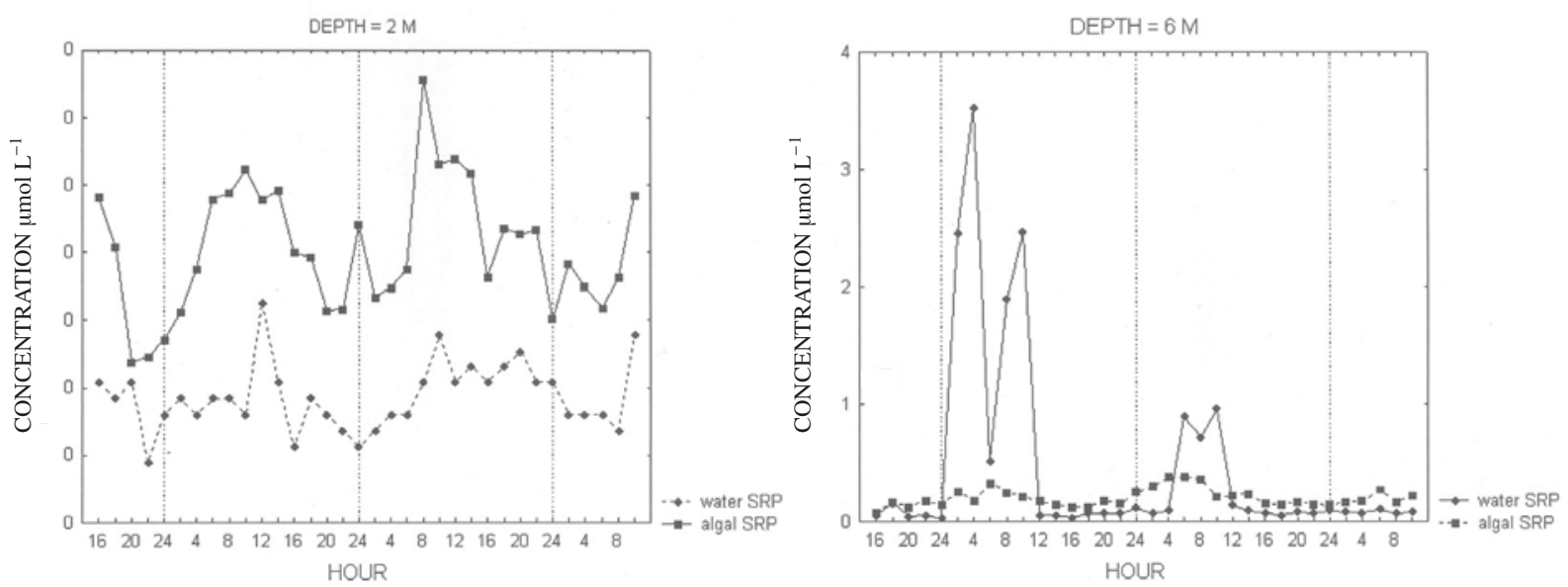

Figure 3. Dissolved inorganic phosphate concentrations (as SRP) in water and within algal cells at both sampling depths in Sau Reservoir during the sampling days. Note the difference of scale on the Y-axis. Concentraciones de fosfato inorgánico disuelto (como $S R P)$ en el agua y dentro de las algas a las dos profundidades del embalse de Sau durante los días de muestreo.

levels in the base of the epilimnion were related to the lower temperature and oxygen concentration and the higher conductivity that characterized Ter River waters.

Total chlorophyll- $a$ content per unit surface was higher during the night and showed a strong decrease in the morning $(8: 00-12: 00 \mathrm{~h})$

Table 1. Mean concentration in $\mu \mathrm{mol} \mathrm{L} \mathrm{L}^{-1}$ of different phosphorus fractions in water (SRP: soluble reactive phosphorus; DOP: dissolved organic phosphorus; PP: particulate phosphorus) and algae (IP: intracellular phosphorus; MP: phosphorus associated to membranes) in Sau Reservoir at two water depths during the sampling days. $N=34$, except for phosphorus concentration at $6 \mathrm{~m}$-depth where $N=27$, because the values of two peaks recorded at this depth were not included. Concentración media en $\mu \mathrm{mol} L^{-1}$ de las diferentes fracciones de fósforo en el agua (SRP: fósforo reactivo soluble; DOP: fósforo orgánico disuelto; PP: fósforo particulado) y en las algas (IP: fósforo intracellular; MP: fósforo asociado a membranes) en el embalse de Sau a dos profundidades en los días del muestreo. $N=34$, excepto para la concentración de fósforo a $6 \mathrm{~m}$ de profundidad en la que $N=27$, debido a que los dos picos medidos a esta profundidad no fueron incluidos.

\begin{tabular}{cccrcr}
\hline & & 2 2 m-depth & \multicolumn{2}{c}{ 6 m-depth } \\
& & concentration & $\%$ & concentration & $\%$ \\
\hline Water & SRP & 0.093 & 7.53 & 0.073 & 6.63 \\
& DOP & 0.256 & 21.40 & 0.265 & 23.33 \\
& PP & 0.881 & 71.07 & 0.795 & 70.04 \\
& Total & 1.239 & 100.00 & 1.135 & 100.00 \\
\hline Algae & IP & 0.581 & 78 & 0.534 & 77 \\
& MP & 0.167 & 22 & 0.160 & 23 \\
& Total & 0.748 & 100 & 0.694 & 100 \\
\hline
\end{tabular}

(Fig. 4). Among all considered variables (air and water temperature, atmospheric pressure, solar radiance, wind velocity, and Wedderburn number), chlorophyll- $a$ concentration per unit surface only showed significant relationships with water temperature $(r=0.39, p<0.05)$ and Wedderburn number $(r=0.49, p<0.01)$.

Table 2. Spearman rank correlations between concentrations of different phosphorus pools in water and in algal cells at the two sampling depths in Sau Reservoir. SRP: soluble reactive phosphorus; DOP: dissolved organic phosphorus; PP: particulate phosphorus; SRPi: intracellular SRP; IP: intracellular phosphorus; MP: phosphorus associated to membranes. ***: $\mathrm{P}<$ 0.001 ; *: $\mathrm{P}<0.01$; *: $\mathrm{P}<0.05$; ns: not significant. Correlaciones de rango de Spearman entre concentraciones de los diferentes grupos de fósforo en el agua y en las algas a las dos profundidades de muestreo en el embalse de Sau. SRP: fósforo reactivo soluble; DOP: fósforo orgánico disuelto; PP: fósforo particulado; SRPi: SRP intracelular; IP: fósforo intracelular; MP: fósforo asociado a las membranes. ***: $P<0.001$; **: $P<0.01$; *: $P<0.05$; ns: no significativo.

\begin{tabular}{llll}
\hline Algae & Water & 2 m-depth & 6 m-depth \\
\hline SRPi & SRP & $0.50 * *$ & $0.69 * * *$ \\
& DOP & $0.35 *$ & $0.39 *$ \\
& PP & $0.59 * * *$ & $0.69 * * *$ \\
\hline IP & SRP & $0.51 * *$ & $0.43 *$ \\
& DOP & $0.45 * *$ & $0.37 *$ \\
& PP & $0.47 * *$ & $0.72 * * *$ \\
\hline MP & SRP & $0.27 \mathrm{~ns}$ & $0.08 \mathrm{~ns}$ \\
& DOP & $0.51 *$ & $0.34 *$ \\
& PP & $0.45 * *$ & $0.26 \mathrm{~ns}$ \\
\hline
\end{tabular}




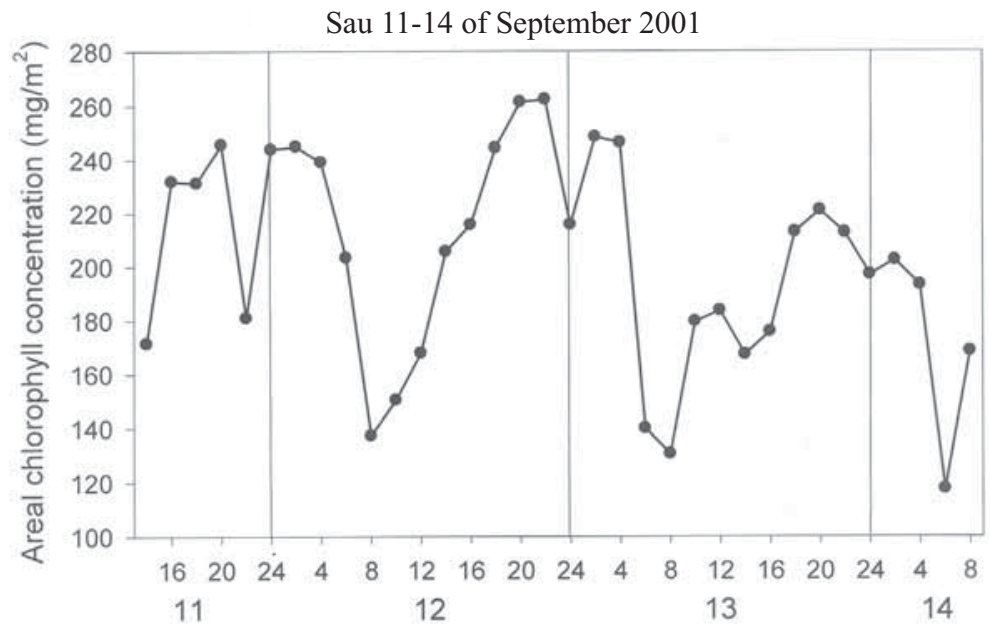

Figure 4. Chlorophyll-a concentration per unit of area during the sampling days in Sau Reservoir. Positive values of wind velocity indicate that wind blew from the dam wall to the river, while negative values indicate the opposite direction. Concentración de clorofila-a por unidad de superficie durante los días de muestreo en el embalse de Sau. Valores positivos en la velocidad del viento indican que el viento sopló desde la presa al río, mientras que valores negativos indican la dirección opuesta.

Total phosphorus content and the relative contribution of the different pools in algal cells were similar at both sampling depths; consequently, phytoplankton community showed no differences in its phosphorus concentration when comparing samples from the upper water layer with those from the bottom of the epilimnion. Intracellular phosphorus pool (IP) was on average $77 \%$ of the total nutrient content, while phosphorus associated to membranes (MP) represented the remaining total pool. Mean SRPi concentration was $0.2 \mu \mathrm{mol} \mathrm{L}-1$; i.e., $36 \%$ of the total intracellular phosphorus content. None of the algal phosphorus pools showed significant correlations with underwater light levels at both sampling depths.

We found positive and highly significant correlations among the different phosphorus pools in water and the intracellular dissolved forms of algal phosphorus (Table 2), but not significant relations resulted between SRP in water and phosphorus associated to algal membranes at both sampled layers.

\section{Chlorophyll-a concentration and environmental phosphorus levels}

Chlorophyll- $a$ profiles showed that phytoplankton community was dominated by Chlorophyceae (1.99-34.56 $\mathrm{g} \mathrm{L}^{-1}$ ), while abundances of the other algal groups (Cryptophyceae, Cyanobacteria and Bacillariophyceae) were lower (0.00-15.06 $\left.\mu \mathrm{g} \mathrm{L}^{-1}\right)$. Epilimnetic chlorophyll- $a$ concentrations were higher during the night and decreased during the morning, and this pattern was consistently observed during the three sampling days. However, the contribution of the different algal groups to these changes was different: decline of chlorophyll- $a$ concentration during the day was related to a decrease of Chlorophyceae, while Cyanobacteria, Cryptophyceae and Bacillarophyceae either maintained similar abundances or increased.

Total chlorophyll- $a$ concentration (in $\mu \mathrm{g} \mathrm{L}^{-1}$ ) showed no significant correlations with the several water phosphorus pools at both sampling depths, because each algal group responds differently to environmental phosphorus levels, and these responses also varied with depth (Fig. 5). At 2 m-depth, chlorophyll- $a$ concentration of Chlorophyceae and Cyanobacteria were significant and negatively related to water dissolved inorganic phosphate (SRP) $(r=-0.42$ with $P<0.01$ and $R=-0.41$ with $P<0.05$, respectively), while Cryptophyceae showed a positive relation $(r=0.44, P<0.05)$ and diatoms were not significantly related. Most of these significant correlations were not maintained at $6 \mathrm{~m}$-depth, 

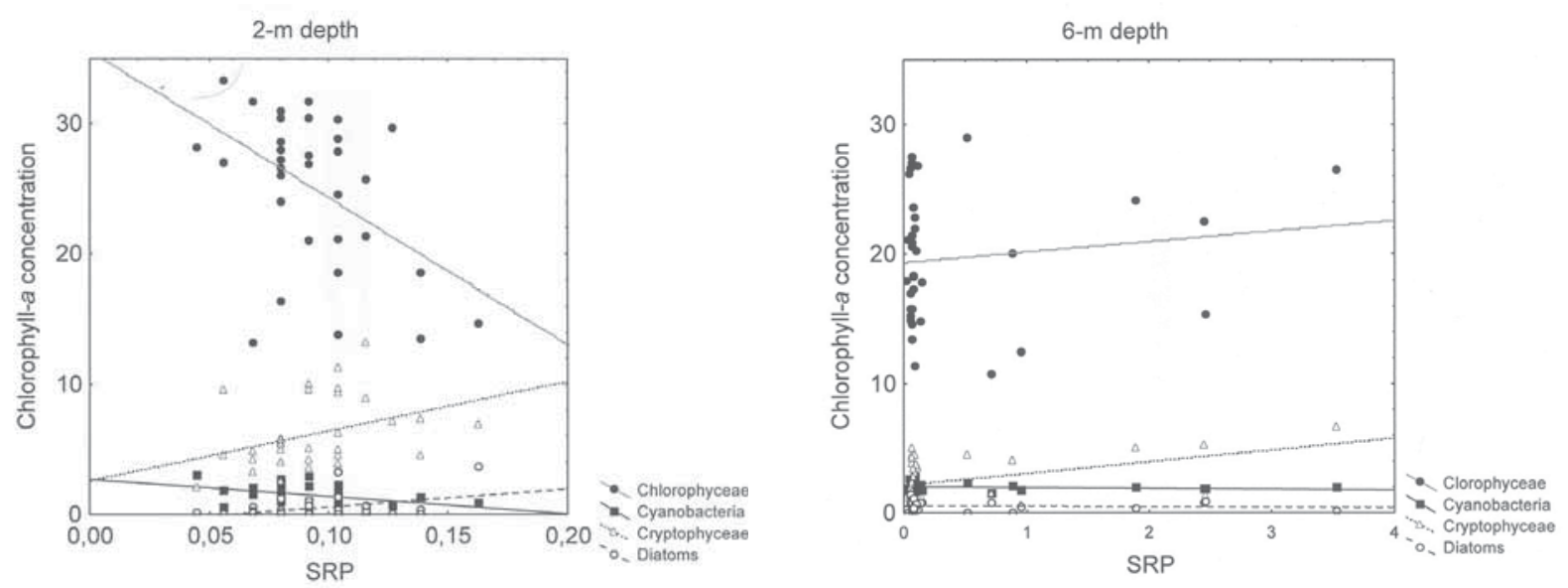

Figure 5. Relationships between water SRP concentration $\left(\mu \mathrm{mol} \mathrm{L}{ }^{-1}\right)$ and chlorophyll- $a$ concentration $\left(\mu \mathrm{g} \mathrm{L}{ }^{-1}\right)$ for the different algal groups at both sampling depths in Sau Reservoir. Linear equations fitted to the points are also indicated. Note the difference of scale on the Y-axis. Relaciones entre concentraciones de SRP y clorofila-a de los diferentes grupos algales en las dos profundidades de muestreo en el embalse de Sau. Se indican también las ecuaciones lineales de ajuste de los puntos.

where only Crytophyceae were significantly related to water SRP $(R=0.40, P<0.05)$. When the dissolved organic forms of phosphorus in waters were considered, significant correlations between DOP concentration and chlorophyll- $a$ content were observed for Cyanobacteria and Cryptophyceae $(R=-0.41$ and $R=0.44$, respectively, with $P<0.05)$ at $2 \mathrm{~m}$-depth, but not for Chlorophyceae and diatoms. Our results indicate that there was not a direct relation between water phosphorus level and total phytoplankton abundance due to the different response of each algal group, and that significant relationships between both variables were discernible at 2 m-depth but not at 6 m-depth.

Concerning irradiance levels, only chlorophyll- $a$ concentration of Cyanobacteria and Cryptophyceae showed significant relations with underwater light levels at $2 \mathrm{~m}$-depth ( $R$-values were, respectively, -0.61 and 0.50 , with $P<0.05)$. Chlorophyll- $a$ contents of all algal groups were not significantly related to irradiance levels at $6 \mathrm{~m}$-depth.

\section{DISCUSSION}

Sau Reservoir was well stratified during the study and the water column showed a high thermal sta- bility. The wind regimen coincided with a daily displacement of metalimnion depth, with thermocline rising during the night when the wind blowed towards the river and with the opposite pattern during the day. According to the epilimnetic water circulation model of Sau Reservoir proposed by Armengol et al. (2005), thermocline oscillation generate internal seiches that are associated with advective movements of surficial water masses, which are alternatively displaced from end to end of the reservoir. The model has been validated by several studies made in Sau Reservoir where interactions between wind, seiches and superficial advective movements were demonstrated (Vidal et al. 2005, Marcé et al. 2007). In addition to this wind-induced water circulation, we observed higher conductivities at the bottom of the epilimnion that indicate the existence of an interflow river circulation moving at an approximately constant depth $(\cong 7 \mathrm{~m})$, without being affected by thermocline tilting. This pattern of river circulation has been consistently observed at the end of summer for many years in Sau Reservoir (Armengol et al. 1999). The interflow circulation further increases thermal stability of the water column and injects phosphorus into the epilimnion due to the high nutrient load of Ter River (Vidal \& Om, 1993; Armengol et al., 1994; Armengol et al. 1999). 
Some authors have documented the input of phosphorus from the hypolimnion of lakes associated to storm events; in some cases this internal load constitutes the main phosphorus entrainment to the epilimnion (Larsen et al., 1981; Soranno et al., 1997). Storm events with high wind velocity transfer kinetic energy to water, eroding the base of the metalimnion and injecting phosphorus from deeper waters to the epilimniom. Phosphorus entrainment is not only increased by the number and strength of storm fronts but by the weakness of stratification. In our study, we recorded two peaks of phosphate concentration at the bottom of the epilimnion during the night and the morning of the first two sampling days. Considering the high thermal stability of the water column and the lack of storms during the study, we cannot attribute the occurrence of these peaks to phosphorus entrainment from the hypolimnion due to thermocline erosion. We observed that dissolved inorganic phosphate levels at the bottom of the epilimnion related positively with conductivity and negatively with water temperature and dissolved oxygen concentration, suggesting that phosphate peaks observed at $6 \mathrm{~m}$-depth originate from the interflow river circulation.

Phosphorus is present in algal cells in several chemical forms. Storage forms are represented by ortophosphates and polyphosphates, while there are four main organic phosphorus fractions: RNA, DNA, and lipid- and ester-phosphorus. Polyphosphates are much more important as storage compounds than phosphates and regulate intracellular levels of ATP, ADP, and phosphates. They are synthesized rapidly transferring phosphate from ATP but are gradually degraded upon resumption of growth and nucleic acid synthesis (Nalewajko \& Lean 1980). In addition to this intracellular phosphorus pool, SañudoWilhelmy et al. (2004) reported the existence of surface-adsorbed phosphorus in different marine algal species. In the centric diatom Thalassiosira weissflogii, surface-adsorbed phosphorus pool $(90 \%)$ in senescent individuals was considerably higher than the amount measured in the exponential growth phase $(30 \%)$, suggesting that phytoplankton have developed mechanisms to access at least some of the surface- adsorbed pool (Sañudo-Wilhelmy et al. 2004). In our study, phosphates represented $36 \%$ of the intracellular pool at both sampling depths, while phosphorus associated to membranes was $23 \%$ of the total pool. Thus, our results suggest that the phytoplankton community was actively growing and not limited by the intracellular accumulated phosphorus. This result might, however, be slightly overestimated because of the filter used in the SRP determinations (GF/F filter instead of $0.45 \mu \mathrm{m}$ filters).

The total phosphorus in a cell fluctuates with changes in the phosphorus supply (Nalewajko \& Lean 1980). In summer, phosphorus turnover times are short and algal cells can replenish their quotas of nutrients very fast, surviving in periods of nutrient starvation. This capacity allows them to integrate and damp the external fluctuations in nutrient availability (Harris, 1986). We found significant relationships between the intracellular phosphorus content and the different phosphorus pools in water which could be explained by this storage capacity. However, phosphorus associated to membranes was not significantly related to dissolved inorganic phosphate, giving some evidence to the hypothesis of Sañudo-Wilhelmy et al. (2004) that phosphorus adsorption to cell surface is caused by an inorganic process rather by active biogenic uptake. Consequently, this pool will not adequately reflect the nutritional status of phytoplankton, a fact that must be taken into account in studies where algal stoichiometry is analysed.

The almost 'automatic' response of algae to phosphorus levels in water was not reflected in changes in the chlorophyll- $a$ content of the phytoplankton community in Sau Reservoir, at least within the 3-day time frame of this study, given that total chlorophyll- $a$ concentration (in $\mu \mathrm{g} \mathrm{L}^{-1}$ ) was not significantly related to water phosphorus levels. The lack of relationship between phytoplankton biomass and water phosphate concentration was also observed by Viner (1989) in an Australian reservoir, where no increase in algal biomass was observed after six days of fertilization with ammonium phosphate. Furthermore, Payne et al. (1988) demonstrated that phosphorus addition to lake water produces luxury phospho- 
rus uptake by the phytoplankton community but no algal response by the way of chlorophyll- $a$ production. A possible explanation is that processes associated to nutrient uptake and biomass construction operate over different time scales. The turnover of the dissolved inorganic phosphate pool in summer may be measured in minutes or seconds, while the algal growth process may be estimated over scales of days and weeks (Harris, 1986). So, changes in phosphorus water concentration will be not reflected in the algal chlorophyll- $a$ content at a diel scale.

Our data also indicate that chlorophyll- $a$ concentration of each algal group showed a different relationship with dissolved inorganic phosphate concentration, and that these relationships were significant at $2 \mathrm{~m}$-depth but not at $6 \mathrm{~m}$ depth (Fig. 5). Most studies have focused on the effects of nutrient addition on the whole phytoplanktonic community through experimental manipulation of the $\mathrm{N}: \mathrm{P}$ ratio, but the influence on the different algal groups has been less analysed. It has been observed that the decrease in $\mathrm{N}: \mathrm{P}$ ratio produces cyanobacterial blooming while the increase in $\mathrm{N}: \mathrm{P}$ ratio most often do not cause the acceleration of Bacillarophyceae biomass, instead it leads to the maximum biomass of Chlorophyceae (Nalewajco \& Lean, 1980; Levich, 1996; Levich \& Bulgakov, 1992). We have not estimated N:P ratios in this study; therefore, comparisons of our data with those of the bibliography are not possible. But, even though a significant correlation between variables does not always imply a causal relationship, our results suggest that algal response to environmental phosphate concentration is variable among taxonomic groups and that underwater light levels somewhat mediate this response. This hypothesis should motivate further research because of its possible consequences on eutrophication processes in lentic environments.

Epilimnetic chlorophyll- $a$ concentration estimated per unit surface showed a diel pattern (Fig. 4) that could not be linked to sedimentation losses, giving that the lowest concentrations values were attained in moments with less stability. The lack of a significant relationship between chlorophyll- $a$ concentration and solar irradiance also suggests that variations in the phytoplankton growth rate cannot explain the observed variability. A diel cycle was also observed for dissolved inorganic phosphate concentration at 2 m-depth, with higher values in the morning and lower ones in the afternoon and the night. As it was said above, our data indicate the existence of a thermocline oscillation associated to wind regimen. Previous studies demonstrated that this is a common pattern in Sau Reservoir and that it is linked to advective surface water movements (Vidal et al. 2005, Marcé et al. 2007). Consequently, we hypothesized that the diel variation of dissolved inorganic phosphate and chlorophyll- $a$ was produced by advection of water masses with different phytoplankton density and phosphate concentration. Similar temporal and spatial dynamics of phytoplankton maxima have been observed in other reservoirs and have been attributed to horizontal patchiness and advective movements (Viner, 1989; Patterson \& Wilson, 1995). However, our results are not conclusive to validate this hypothesis.

The light-nutrient hypothesis states that phytoplankton $C$ :nutrient ratios are driven by the ratio of available light and nutrients, and it was supported by studies using different approaches. For example, Sterner et al. (1997) analysed the hypothesis integrating data from the epilimnion of a broad range of lakes, while Dickman et al. (2006) experimentally quantified the effects of light and nutrients on intact phytoplankton assemblages from reservoirs of varying productivity. Here, we compared phosphorus content in phytoplankton assemblages situated at different depths and, as a result, receiving different underwater light level. We found no differences in algal phosphorus concentration at both sampling depths and no significant relationships between irradiance and the different algal phosphorus pools. Consequently, the prediction that phosphorus content will be greater at higher depth is not supported by our data. It must be taken into account that the response of phytoplankton stoichiometry to light and nutrients can be highly variable. Dickman et al. (2006) suggested that highly diverse assemblages may exhibit greater flexibility in their response than assemblages 
with lower diversity. Klausmeier et al. (2004) proposed that relative algal phosphorus content might vary depending on whether phytoplankton is under exponential growth or at competitive equilibrium under different limiting resources (nitrogen, phosphorus, and light). In addition to this, within a phytoplanktonic assemblage each species has distinct growth and mortality rates and nutrient storage capacity. All these factors could contribute to the lack of effects of light on algal nutrient content in this study.

The results of this work emphasize (1) the complexity of the links between environmental phosphate concentration and phytoplanktonic phosphorus content and biomass, and (2) the importance of scale in analysing such relationships. The response of algae to water phosphorus levels also seems to be mediated by light, not with respect to the intracellular phosphorus content -as proposed by the light:nutrient hypothesis, but turning relationships between biomass and environmental phosphorus more 'apparent'. Moreover, algal nutrient content may be influenced not only by environmental light and nutrient levels but also by several factors, including assemblage diversity and characteristics of the phytoplanktonic populations that are variable among species. Future studies on the relationships between algae and environmental nutrient levels should consider phytoplankton composition to quantify the differential response of each algal taxon.

\section{ACKNOWLEDGEMENTS}

The authors wish to thank María de los Angeles Gallegos for her assistance with laboratory and fieldwork and Adonis Giorgi for its helpful comments on the manuscript. The limnological study of Sau Reservoir is part of a long-term study supported by Aigües Ter-Llobregat (ATLL). This project has been partially funded by the Ministerio de Ciencia y Tecnología (Projects REN20012185-CO2-O2 and CGL2004-05503-CO2-01). The postdoctoral staying of C. Feijoó at the Universitat de Barcelona was partially supported by the Universidad Nacional de Luján and ATLL. Rafael Marcé is granted of the Minis- terio de Educación, Cultura y Deportes. The contribution of the Comisión Interministerial de Ciencia y Tecnología (CIRIT) of the Generalitat de Catalunya is greatly appreciated.

\section{REFERENCES}

ALEYA, L. 1991. Ecophysiological significance of the diel biochemical changes of particulates coupled with metabolic and environmental parameters in two trophically different lakes. Arch. $\mathrm{Hy}$ drobiol., 120: 403-432.

ARMENGOL, J., J. TOJA \& A. VIDAL. 1994. Seasonal rhythm and secular changes in Spanish reservoirs. In: Limnology now: A paradigm of planetary problems. Margalef, R. (ed.): 237-253. Elsevier Science, Amsterdam.

ARMENGOL, J., J. C. GARCÍA, M. COMERMA, M. ROMERO, J. DOLZ, M. ROURA, B. H. HAN, A. VIDAL \& K. SIMEK. 1999. Longitudinal processes in canyon type reservoirs: The case of Sau (N.E. Spain). In: Theoretical Reservoir Ecology and its Applications. Tundisi, J. G. \& M. Straskraba (eds.): 313-345. Brazilian Academy of Sciences and Backjhuys Publishers, Leiden.

ARMENGOL, J., E. NAVARRO, L. CAPUTO \& J. DOLZ. 2005. Viento, estabilidad térmica y ondas internas: bases para una gestión de los embalses a corto plazo. In: Tercer Taller Internacional de Eutrofización de lagos y embalses. I. Vila \& J. Pizarro (eds.): 29-50. CYTED XVIIB, Santiago. Chile.

APHA. 1992. Standard methods for the examination of water and wastewater. $18^{\text {th }}$ Ed. APHA, Washington D.C. 1100 pp.

BARBOSA, F. A. R., J. G. TUNDISI \& R. HENRY. 1989. Diel variations in a shallow tropical Brazilian lake II. Primary production, photosynthetic efficiency and chlorophyll-a content. Arch. Hydrobiol., 116: 435-448.

BEUTLER M., K. W. WILTSHIRE, B. MEYER, C. MOLDAENKE, C. LÜRING, M. MEYERHÖFER, U. P. HANSEN \& H. DAU. 2002. A fluorometric method for the differentiation of algal populations in vivo and in situ. Photosynthesis Research, 72: 39-53.

BOAVIDA, M. J. \& R. T. HEATH. 1984. Are the phosphatases released by Daphnia magna components of its food? Limnol. Oceanogr., 29: 641-645. COMERMA, M. 2003. Processos heterotròfics mi- 
crobians a l'embassament de Sau. Doctoral thesis, University of Barcelona. 192 pp.

DICKMAN, E. M., M. J. VANNI \& M. J. HORGAN. 2006. Interactive effects of light and nutrients on phytoplankton stoichiometry. Oecologia, 149: 676-689.

DODDS, W. K. 1993. What controls levels of dissolved phosphate and ammonium in surface waters? Aquatic Sciences, 55: 132-142.

DROOP, M. R. 1983. 25 years of algal growth kinetics. A personal view. Botanica Marina, 26: 99-112.

GRASSHOFF, K., M. ERHARDT \& K. KREMLING. 1983. Methods of seawater analysis. $2^{\text {ond }}$ Ed. Wiley-VCH, Weinheim. 419 pp.

HARRIS, G. P. 1986. Phytoplankton Ecology. Chapman and Hall, London. 384 pp.

IMBERGER, J. \& J. C. PATTERSON. 1990. Physical limnology. In: Advances in Applied Mechanics vol. 27. T. Wu (ed.).: 303-475. Academic Press, Boston.

KLAUSMEIER, C. A., E. LITCHMAN, T. DAUFRESNE \& S. A. LEVIN. 2004. Optimal nitrogen to phosphorus stoichiometry of phytoplankton. Nature, 429: 171-174.

KOMÁRKOVA, J. \& J. HEJZLAR. 1996. Summer maxima of phytoplankton in the Ïímov Reservoir in relation to hydrologic parameters and phosphorus loading. Arch. Hydrobiol., 136: 217-236.

LARSEN, D. P., D. W. SCHULTS \& K. W. MALUEG. 1981. Summer internal phosphorus supplies in Shagawa Lake, Minnesota. Limnol. Oceanogr., 26: 740-753.

LEBOULANGER C., U. DORIGO, S. JACQUET, B. LE BERRE, G. PAOLINI \&. J. F. HUMBERT. 2002. Application of a submersible spectrofluorometer for rapid monitoring of freshwater cyanobacterial blooms: a case study. Aquat. Microb. Ecol., 30: 83-89.

LEVICH, A. P. 1996. The role of nitrogen-phosphorus ratio in selecting for dominance of phytoplankton by cyanobacteria or green algae and its application to reservoir management. Journal of Aquatic Ecosystem Health, 5: 55-61.

LEVICH, A. P. \& N. G. BULGAKOV. 1992. Regulation of species and size composition in phytoplankton communities in situ by N:P ratio. Russian Journal of Aquatic Ecology., 1: 149-158.

MARCÉ, R., C. FEIJOÓ, E. NAVARRO, J. ORDOÑEZ, J. GOMÀ \& J. ARMENGOL. 2007. Interaction between wind-induced seiches and convective cooling governs algal distribution in a canyon-shaped reservoir. Freshwat. Biol., 52(7): 1336-1352.
NALEWAJKO, C. \& D. R. S. LEAN. 1980. Phosphorus. In: The physiological ecology of phytoplankton. I. Morris (ed.).: 235-258. Blackwell Scientific Publications, Oxford.

PATTERSON, G. \& K. K. WILSON. 1995. The influence of the diel climatic cycle on the depth-time distribution of phytoplankton and photosynthesis in a shallow equatorial lake (Lake Baringo, Kenya). Hydrobiologia, 304: 1-8.

PAYNE, G. W., E. WHITE, S. E. PICKMERE, \& P. H. WOODS. 1988. Algal responses to nitrogen and phosphorus additions in four central North Island, New Zealand lakewaters. Verh. Internat. Verein. Limnol., 23: 602-606.

PRÉZELIN, B. B. 1992. Diel periodicity in phytoplankton productivity. Hydrobiologia, 238: 1-35.

SAUDO-WILHELMY, S. A., A. TOVAR SÁNCHEZ, F. X. FU, D. G. CAPONE, E. J. CARPENTER \& D. A. HUTCHINS. 2004. The impact of surfaceadsorbed phosphorus on phytoplankton Redfield stoichiometry. Nature, 432: 897-901.

SORANNO, P. A., S. R. CARPENTER \& R. C. LATHROP. 1997. Internal phosphorus loading in Lake Mendota: response to external loads and weather. Can. J. Fish. Aquat. Sci., 54: 1 883-1 893.

STERNER, R. W., J. J. ELSER, E. J. FEE, S. J. GUILFORD \& T. H.CHRZANOWSKI. 1997. The light:nutrient ratio in lakes: tha balance of energy and materials affects ecosystem structure and process. The American Naturalist, 150(6): 663-684.

THORENSEN, S. S., Q. DORTCH \& S. I. AHMED. 1982. Comparison of methods for extracting intracellular pools of inorganic nitrogen from marine phytoplankton. J. Plankton Res., 4: 695-704.

TILMAN, D. 1982. Resource Competition and Community structure. Princeton University Press, Princeton, N. J. 296 pp.

VIDAL, A. \& J. OM. 1993. The eutrophication process in Sau Reservoir (NE Spain): A long term study. Verh. Internat. Verein. Limnol., 25: 1 247-1 256.

VIDAL, J., X. CASAMITJANA, J. COLOMER \& T. SERRA. 2005. The internal wave field in Sau reservoir: Observation and modeling of a third vertical mode. Limnol. Oceanogr., 50: 1 326-1 333.

VINER, A. B. 1989. Fluorescence and carbon fixation by phosphorus deficient phytoplankton in a Western Australian reservoir. Arch. Hydrobiol., 115: 1-19.

WETZEL, R. G. 2001. Limnology: Lake and River Ecosystems. $3^{\text {rd }}$ Ed. Academic Press, San Diego. $850 \mathrm{pp}$. 